\title{
CONGESTIVE HEART FAILURE AND COGNITIVE FUNCTIONING AMONGST OLDER ADULTS
}

\author{
Osvaldo P. Almeida', Sérgio Tamai
}

\begin{abstract}
Background: Congestive heart failure is associated with decline in quality of life and, possibly, cognitive functions such as memory and attention. Aims: The present study was designed to investigate the presence of cognitive impairment amongst patients with congestive heart failure (CHF). We hypothesised that CHF patients would have lower scores than elderly controls on general measures of cognitive functioning. Methods and Results: We examined a sample of 50 consecutive patients admitted to hospital with CHF functional class III/IV and a convenience sample of 30 older adults assessed the outpatient service of geriatric medicine of a teaching hospital in São Paulo, Brazil. All subjects were interviewed with the Cambridge Examination for Mental Disorders of the Elderly (CAMDEX), as well as the neuropsychological battery of the CAMDEX (CAMCOG), Mini-Mental State Examination (MMSE), Trail Making A and B, Digit Span, Digit Symbol, and Letter Cancellation Test. All CHF patients had left ventricular ejection fraction (EF) below $45 \%$ and all controls above $65 \%$. The cognitive performance of CHF patients was significantly worse than controls for all cognitive assessments. Twenty-seven of 50 CHF patients had a MMSE total score lower than 24, compared with only $10 / 30$ controls $(p=0.073)$. Similarly, $36 / 49$ and $9 / 30$ CHF subjects and controls respectively had CAMCOG scores below $80(p<0.001)$. Cognitive scores were significantly associated with $E F$, which was the most robust predictor of cognitive impairment according to the CAMCOG in a logistic regression model. Conclusion: Our results indicate that CHF is associated with significant levels of cognitive impairment and show that mental performance is, at least partly, a consequence of EF. Physicians should be prepared to assess the mental state of patients, as poor cognitive functioning may interfere with treatment compliance and management plan.
\end{abstract}

KEY WORDS: congestive heart failure, heart, attention, memory, neuropsychology, cognition, mental state.

\begin{abstract}
Insuficiência cardíaca congestiva e funcionamento cognitivo entre idosos
RESUMO - Pano de fundo: Insuficiência cardíaca congestiva está associada a declínio da qualidade de vida e, possivelmente, de funções cognitivas como memória e atenção. Objetivo: Este estudo foi desenhado com o objetivo de investigar a presença de compromentimento cognitivo entre pacientes com insuficiência cardíaca congestiva (ICC) e testar a hipótese de que pacientes com ICC apresentam escores mais baixos em testes neuropsicológicos. Método e Resultados: 0 estudo avaliou 50 pacientes com ICC classe funcional III/IV atendidos de forma consecutiva no serviço de emergência cardíaca do Instituto do Coração e uma amostra de 30 controles idosos recrutada do serviço ambulatorial do Departamento de Geriatria do Hospital das Clínicas de São Paulo, Brasil. Todos foram entrevistados com a versão brasileira do 'Cambridge Examination for Mental Disorders of the Elderly' (CAMDEX), bem como com a bateria neuropsicológica do CAMDEX (CAMCOG), MiniExame do Estado Mental (MMSE), Teste das Trilhas A e B, Span de Dígitos, Substituição de Dígitos por Símbolos, e Teste do Cancelamento de Letras. Todos os pacientes com ICC apresentavam fração de ejeção (FE) ventricular esquerda $<45 \%$ e todos os controles $\mathrm{FE}>65 \%$. O desempenho cognitivo de pacientes com ICC foi significativamente pior que dos controles em todos os testes. Vinte e sete dos 50 pacientes com ICC e 10/30 controles tiveram escores menores do que 24 no MMSE $(p=0.073)$. De forma semelhante, $36 / 49$ e $9 / 30$ dos pacientes e controles tiveram escores no CAMCOG < $80(p<0.001)$. Os escores do CAMCOG estavam significativamente associados com a FE do ventrículo esquerdo em um modelo de regressão logística. Conclusão: Os resultados deste estudo indicam que a ICC está associada a declínio das habilidades cognitivas e que esta, por sua vez, é influenciada pela FE do ventrículo esquerdo. Clínicos que trabalham com pacientes com ICC devem estar preparados para investigar o estado mental de seus pacientes, já que o declínio cognitivo pode interferir com aderência e plano de tratamento.
\end{abstract}

PALAVRAS-CHAVE: insuficiência cardíaca congestiva, coração, atenção, memória, neuropsicologia, cognição, estado mental.

\footnotetext{
${ }^{1} \mathrm{MD}, \mathrm{PhD}$, FRANZCP University of Western Australia, Perth WA, Australia. ${ }^{2} \mathrm{MD}$, PhD, Santa Casa Medical School, São Paulo SP, Brazil. This study was supported by a research grant from 'Fundação Amparo à Pesquisa do Estado de São Paulo - FAPESP, Brazil.
}

Received 23 November 2000, received in final form 18 January 2001. Accepted 23 January 2001.

Osvaldo P. Almeida, MD - UWA Department of Psychiatry, Mental Health Unit for the Elderly, Royal Perth Hospital, Level 6, Ainslie House, GPO Box X2213, Perth, WA 6847, Austrália; Email: osvalm@cyllene.uwa.edu.au. 
Congestive heart failure (CHF) is a common consequence of most diseases of the heart and a leading cause of hospitalisation, morbidity and mortality in Western societies ${ }^{1,2}$. The findings of several surveys indicate that physical, social, work, and leisure activities are significantly impaired amongst $\mathrm{CHF}$ patients ${ }^{3,4}$. Psychological distress is also frequent, with the results of recent studies suggesting that more than $50 \%$ of patients with CHF admitted to hospital are depressed ${ }^{5}$. Another important, but neglected, aspect of the quality of life of people with $\mathrm{CHF}$ is cognition. Early reports indicated that up to $80 \%$ of patients with severe CHF show signs of cognitive impairment ${ }^{6}$. The consequences of these deficits remain unclear, but it is conceivable that patients with cognitive impairment have even higher morbidity and mortality rates. For example, Cline et al. ${ }^{7}$ reported that 10 of their 22 patients were unable to name the medication they were receiving for the treatment of CHF, 11/22 could not state the doses, and 14/22 failed to remember when to take their tablets. All subjects were surveyed 30 days after receiving detailed verbal and written information about their treatment regimen. Failing to take the prescribed medication, in such cases, may increase the frequency of clinical complications associated with $\mathrm{CHF}^{8-13}$.

Attentional skills may be particularly vulnerable to the effects of CHF. Gorkin et al. ${ }^{8}$ used a case-control study design to investigate the effects of $\mathrm{CHF}$ on the cognitive performance of 158 patients-NYHA functional class I and 150 subjects-functional class II/III. Cognitive assessment included the use of the vocabulary subtest of the WAIS-revised, digit span, and trail making A \& B. Patients with CHF-NYHA-II/III had significantly poorer digit span and trail A scores than NYHA-I subjects. Subsequent studies confirmed that $\mathrm{CHF}$ is associated with cognitive impairment ${ }^{9-14}$ and that more than $50 \%$ of patients have Mini Mental State Examination scores (MMSE) within the dementia range $(\mathrm{MMSE}<24 / 30)^{14}$. The results of these studies also show that some, but not all, cognitive skills improve with CHF treatment ${ }^{6,10}$.

We designed this study to investigate the presence of cognitive deficits amongst CHF patients admitted to hospital. We hypothesised that the performance of CHF patients on attentional tasks would be impaired relative to controls and that cognitive scores would be associated with left ventricular ejection fraction.

\section{METHOD}

Consecutive CHF patients admitted to the Emergency Department of the Heart Institute in São Paulo, Brazil, were considered eligible to take part in the study if they fulfilled the following criteria: (1) clinical diagnosis of CHF functional class III-IV ${ }^{15,16}$; (2) age 60 years or over and; (3) left ventricular ejection fraction rate (EF) lower than $45 \%$. Subjects with the following characteristics were excluded from the study: (1) history of myocardial infarction 3 months or less prior to assessment; (2) history of stroke associated with the development of neurological signs or symptoms; (3) chronic obstructive lung disease; (4) visual impairment that compromised reading (font size 20) and; (5) presence of a depressive or other psychiatric disorder according to ICD-10; (6) failure to provide written informed consent elderly controls (aged 60 years or over) were selected from an outpatient geriatric clinical service at the same hospital. They all had EF $>65 \%$ and did not meet any of the exclusion criteria described above.

\section{Procedures}

EF was calculated through the formula (final diastolic volume - final systolic volume)/final diastolic volume. All measures were obtained with bidimensional ecocardiogram. Subjects were then assessed with the Cambridge Examination for Mental Disorders of the Elderly (CAMDEX), which incorporates a general cognitive battery known as CAMCOG $^{17}$. In addition, the cognitive assessment of patients included the Digit Span and Digit-Symbol subtests of the Wechsler Intelligence Scale-Revised (WAIS-R) ${ }^{18}$, Letter Cancellation Test ${ }^{19}$, and Trail Making $A$ and $\mathrm{B}^{19}$. These tests are reliable measures of psychomotor speed and attention $^{19}$. All CHF cases were examined within 72 hours after admission to hospital.

All participants were informed about the aims and procedures of the study and asked to sign an informed consent form. This research project was approved by the 'Hospital das Clínicas' Ethics Committee and complies with the Declaration of Helsinki.

\section{Statistical analysis}

The data were analysed with the statistical package 'Stata $6.0^{\prime 20}$. The association between categorical variables was examined through the analysis of contingency tables, with the statistical results being distributed as Pearson's chi-square $\left(\chi^{2}\right)$. Fisher's Exact Test (FET) was used in the analysis of $2 \times 2$ tables that had expected values below or equal 5 for 2 or more of the cells. Between group differences for continuous (in practical terms) variables was estimated with Student's t-test, whereas Mann-Whitney nonparametric test was used in the analysis of ordinal data. Analysis of covariance was employed to calculate betweengroup differences when confounders needed to be included in the analysis. Spearman rho correlation coefficient was calculated for the association between cognitive scores and EF. Logistic regression was used to investigate the effect of multiple variables on cognitive scores. Ninety-five percent confidence intervals $(\mathrm{Cl})$ were estimated for the mean and odds ratio. 
Table 1. Demographic and clinical information as ascertained by the CAMDEX

\begin{tabular}{|c|c|c|c|c|c|}
\hline & & CHF $n=50$ & Controls $n=30$ & $\mathrm{t} / \chi^{2}$ & $\mathrm{p}$ \\
\hline \multirow{2}{*}{ Age (mean years) } & & 67.30 & 76.70 & 6.06 & 0.000 \\
\hline & $\mathrm{Cl}$ & 65.57 to 69.03 & 73.84 to 79.55 & & \\
\hline \multirow[t]{2}{*}{ Age at which subject left school (mean years) } & & 12.83 & 14.30 & 0.56 & 0.577 \\
\hline & $\mathrm{Cl}$ & 8.70 to 16.97 & 12.97 to 15.63 & & \\
\hline Gender ( $\%$ males) & & 76.0 & 66.7 & 0.82 & 0.365 \\
\hline \multicolumn{6}{|l|}{ Clinical symptoms: } \\
\hline Cerebrovascular symptoms (\%) & & 16.0 & 13.3 & 0.10 & 0.476 \\
\hline Sleep problems (\%) & & 16.0 & 36.7 & 4.42 & 0.035 \\
\hline Anxiety symptoms (\%) & & 26.0 & 30.0 & 0.15 & 0.698 \\
\hline Subjective memory difficulties (\%) & & 18.0 & 40.0 & 4.69 & 0.030 \\
\hline Paranoid symptoms (\%) & & 0 & 3.3 & FET & 0.375 \\
\hline \multicolumn{6}{|l|}{ Prior medical history of: } \\
\hline Heart attack (\%) & & 38.0 & 10.0 & 7.37 & 0.007 \\
\hline Hypertension (\%) & & 64.0 & 50.0 & 1.52 & 0.218 \\
\hline Stroke (\%) & & 14.0 & 0 & FET & 0.041 \\
\hline Brain injury (\%) & & 8.0 & 20.0 & 2.47 & 0.116 \\
\hline Epilepsy/Seizures (\%) & & 0 & 6.7 & FET & 0.138 \\
\hline Smoking >20 cigarettes/day (\%) & & 52.0 & 23.3 & 6.36 & 0.012 \\
\hline Regular alcohol consumption (\%) & & 28.0 & 0 & FET & 0.001 \\
\hline
\end{tabular}

FET, Fisher's Exact Test.

\section{RESULTS}

Fifty CHF patients and 30 controls met the inclusion criteria for the study. Their demographic and clinical features are displayed on Table 1. CHF subjects were significantly younger than controls. In addition, they were less likely to complain of sleep and memory difficulties, but more likely to report prior history of heart attack, strokes, smoking and alcohol consumption.

CHF patients had significantly worse cognitive scores than controls for most cognitive tests (Table 2). These differences became even more pronounced when scores were adjusted for age. Analysis of covariance showed that patients had significantly lower CAMCOG $(F=24.89, p<0.001)$ and MMSE $(F=15.16$, $p<0.001)$ scores. Twenty-seven of the 50 CHF patients had a MMSE total score lower than 24, compared with only $10 / 30$ controls $\left(\chi^{2}=3.22, p=0.073\right)$. Similarly, 36/49 (one missing case) and 9/30 CHF subjects and controls respectively had CAMCOG scores below $80\left(\chi^{2}=14.34, p<0.001\right)$.

The mean EF was $37.0 \%(\mathrm{Cl}=35.2$ to 38.7 ; range $=21$ to 45 ) for CHF patients and $74.2 \%$ $(\mathrm{Cl}=72.7$ to 75.6 ; range $=66$ to 81$)$ for controls. $\mathrm{EF}$ was significantly associated with cognitive scores, including the CAMCOG ( $r h o=0.40, p<0.001)$, MMSE (rho $=0.29, p=0.011)$, digit span ( $r h o=0.25$, $p=0.026)$, digit symbol $(r h o=0.45, p<0.001)$, letter cancellation (rho $=0.33, p=0.001)$, trail $A(r h o=$ $-0.28, p=0.013)$, and trail $B(r h o=-0.34, p=0.003)$. Logistic regression using cognitive impairment on the CAMCOG as the dependent variable $(0 / 79=\mathrm{im}$ paired; 80/107=not impaired) and EF, age, complaints of sleep and memory problems, prior history of heart attack, stroke, smoking and alcohol abuse as independent variables showed that EF was the strongest predictor of cognitive impairment ( $\mathrm{OR}=7.61, \mathrm{Cl}=2.03$ to 28.48 ) in our study sample (Table 3).

\section{DISCUSSION}

The results of the present study indicate that CHF is associated with significant decline in cognitive functioning, with almost 3/4 of CHF patients scoring within the 'impaired range' on the CAMCOG. Fifty-four percent of our cases had MMSE scores lower than 24 at the time of admission to hospital. Similar rates of cognitive impairment were reported by others amongst CHF patients assessed prior to discharge from hospital ${ }^{13}$.

We also found that the performance of CHF patients on attention tasks was impaired relative to controls. Acanfora et al. ${ }^{9}$ described that their 183 CHF patients had lower attentional matrices scores 
Table 2. Cognitive scores of CHF patients and controls.

\begin{tabular}{|c|c|c|c|c|c|}
\hline & & $\mathrm{CHF} n=50$ & Controls $n=30$ & $t / z$ & $\mathrm{p}$ \\
\hline \multicolumn{6}{|l|}{ CAMCOG (mean) } \\
\hline \multirow[t]{2}{*}{ - orientation } & & 8.82 & 9.60 & 2.40 & 0.016 \\
\hline & $\mathrm{Cl}$ & 8.35 to 9.28 & 9.33 to 9.87 & & \\
\hline \multirow[t]{2}{*}{ - language } & & 22.42 & 25.17 & 3.85 & 0.000 \\
\hline & $\mathrm{Cl}$ & 21.33 to 23.51 & 24.27 to 26.06 & & \\
\hline \multirow[t]{2}{*}{ - attention } & & 3.52 & 3.93 & 1.13 & 0.189 \\
\hline & $\mathrm{Cl}$ & 2.94 to 4.09 & 3.23 to 4.63 & & \\
\hline \multirow[t]{2}{*}{ - memory } & & 17.12 & 20.20 & 3.22 & 0.001 \\
\hline & $\mathrm{Cl}$ & 15.76 to 18.49 & 18.84 to 21.56 & & \\
\hline \multirow[t]{2}{*}{ - praxis } & & 7.68 & 9.00 & 2.24 & 0.025 \\
\hline & $\mathrm{Cl}$ & 6.96 to 8.40 & 8.22 to 9.78 & & \\
\hline \multirow[t]{2}{*}{ - calculation } & & 1.88 & 1.93 & 0.53 & 0.598 \\
\hline & $\mathrm{Cl}$ & 1.77 to 1.99 & 1.84 to 2.03 & & \\
\hline \multirow[t]{2}{*}{ - abstraction } & & 2.98 & 5.23 & 4.42 & 0.000 \\
\hline & $\mathrm{Cl}$ & 2.42 to 3.53 & 4.56 to 5.91 & & \\
\hline \multirow[t]{2}{*}{ - perception } & & 7.10 & 6.90 & 0.82 & 0.414 \\
\hline & $\mathrm{Cl}$ & 6.72 to 7.48 & 6.49 to 7.31 & & \\
\hline \multirow[t]{2}{*}{ - Total score } & & 71.82 & 81.97 & 3.80 & 0.000 \\
\hline & $\mathrm{Cl}$ & 68.16 to 75.47 & 78.54 to 85.39 & & \\
\hline \multirow[t]{2}{*}{ MMSE (mean) } & & 22.90 & 25.03 & 2.59 & 0.011 \\
\hline & $\mathrm{Cl}$ & 21.83 to 23.97 & 23.84 to 26.22 & & \\
\hline \multirow[t]{2}{*}{ Digit Span (mean) } & & 3.84 & 5.13 & 3.07 & 0.002 \\
\hline & $\mathrm{Cl}$ & 3.47 to 4.20 & 4.44 to 5.82 & & \\
\hline \multirow[t]{2}{*}{ Digit Symbol (mean) } & & 10.34 & 19.30 & 4.06 & 0.000 \\
\hline & $\mathrm{Cl}$ & 8.17 to 12.51 & 14.76 to 23.84 & & \\
\hline \multirow[t]{2}{*}{ Letter Cancellation (mean) } & & 29.94 & 40.33 & 3.08 & 0.002 \\
\hline & $\mathrm{Cl}$ & 25.87 to 34.01 & 34.47 to 46.19 & & \\
\hline \multirow[t]{2}{*}{ Trail A (mean) } & & 36.22 & 22.23 & -1.77 & 0.077 \\
\hline & $\mathrm{Cl}$ & 24.76 to 47.68 & 17.09 to 27.58 & & \\
\hline \multirow[t]{2}{*}{ Trail B (mean) } & & 72.86 & 36.03 & -2.84 & 0.004 \\
\hline & $\mathrm{Cl}$ & 53.24 to 92.47 & 26.64 to 45.42 & & \\
\hline
\end{tabular}

Table 3. Logistic regression analysis using cognitive impairment according to CAMCOG scores as independent variable

\begin{tabular}{lll}
\hline & OR & $\mathrm{Cl}$ \\
\hline EF (0-30 / 31/45 / 45+) & 7.61 & 2.03 to 28.48 \\
Age (years) & 0.93 & 0.86 to 1.01 \\
Sleep complaints (no/yes) & 0.52 & 0.14 to 1.93 \\
Memory complaints (no/yes) & 1.09 & 0.33 to 3.64 \\
Prior history of heart attack (no/yes) & 0.86 & 0.25 to 2.98 \\
Prior history of stoke (no/yes) & 1.28 & 0.19 to 8.87 \\
Prior history of smoking 20 or more cigarettes/day (no/yes) & 1.21 & 0.39 to 3.72 \\
Prior history of heavy alcohol consumption (no/yes) & 0.47 & 0.10 to 2.21 \\
\hline
\end{tabular}




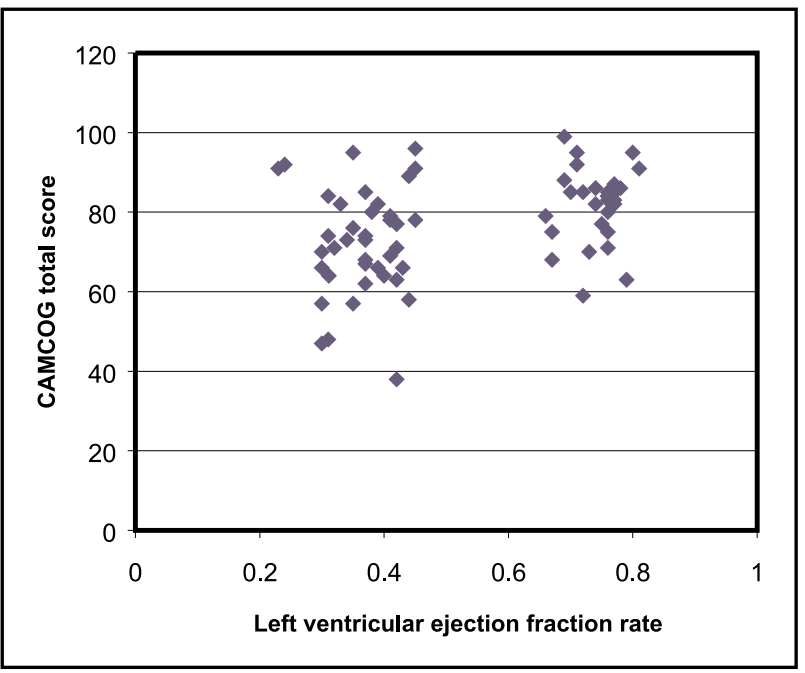

Fig 1. Graphic distribution of the association between CAMCOG scores and left ventricular ejection fraction rate amongst patients with CHF (left) and elderly controls (right hand side).

than 202 older adults with heart diseases other than $\mathrm{CHF}$, whereas Putzke et al. ${ }^{21}$ observed that trail making $B$ results were significantly worse for 44 heart transplant candidates than 44 matched controls recruited from the community. It is, therefore, conceivable that the attentional deficits experienced by patients with CHF contribute to the pattern of generalised cognitive impairment that we and others observed ${ }^{13,14}$. There is also evidence that attentional deficits become more prominent with increasing CHF severity. Gorkin et al. ${ }^{8}$ found that their 150 subjects with CHF functional class II/III had significantly worse digit span and trail making A scores than the 158 patients functional class I. Treatment of heart failure, on the other hand, seems to improve some of these cognitive deficits. Shall et al. ${ }^{6}$ found that the results of 20 patients on the performance subtests of the WAIS improved after cardiac transplant. However, memory subscores remained abnormally low even after surgery ${ }^{6,10}$.

Our results indicate that cognition is associated with $E F$, although the association between EF and CAMCOG scores is weak when only CHF patients $(S p e a r m a n=0.11)$ or controls (Spearman $=0.12)$ are included in the analysis (Fig 1 ). In addition, we failed to observe the linearity between cognitive scores and EF reported by another study ${ }^{13}$, which would suggest that cognitive performance is not a simple and direct consequence of EF or cardiac output ${ }^{11}$. It is likely that other factors such as the presence of cerebrovascular disease, hormonal changes, and medication use interact with cardiological variables to modulate brain activity and function of $\mathrm{CHF}$ pa- tients. This area of research requires further investigation.

Our study has limitations that need to be taken into account before its results can be generalised. First, our sample was formed by a selective group of patients conveniently recruited from two specialised medical services of a teaching hospital - at this point, it is unclear how well they represent the CHF and geriatric population. In addition, controls and CHF subjects were not well matched for age, although this would represent a 'cognitive disadvantage' for controls rather than CHF patients. Second, the number of subjects recruited for the study was relatively modest. Third, it is unclear at this stage whether some of the deficits observed in our study are actually secondary to the physical rather than mental consequences of CHF. We believe this is unlikely to be the case, as previous reports suggest that cognitive deficits remain even after successful CHF treatment ${ }^{6}$. Finally, we need to acknowledge that the investigator involved with the administration of all tests (ST) was not blind to the medical condition of patients, although the highly structured testing procedure makes it less likely that rating bias would have been introduced.

In summary, the results of the present study indicate that $\mathrm{CHF}$ is associated with significant impairment of cognitive functioning. Future studies should aim to clarify the mechanisms leading to cognitive impairment amongst CHF patients, as wells as the best strategy to prevent and treat such deficits. For the moment, it is important that clinicians be made aware of this association, as it may have critical implications for the management of CHF patients.

Acknowledgements - The authors are in debt with Dr M Ochiai, Prof AC Pereira Barreto and Prof M Wajngarten for their support with the recruitment of patients and for making the results of ecocardiogram studies available to us. We are also grateful to Prof ET Carvalho Filho and Prof Wilson Jacob for their kind assistance with the recruitment of controls.

\section{REFERENCES}

1. Watson RDS, Gibbs CR, Lip GYH. ABC of heart failure: clinical features and complications. BMJ 2000;320:236-239.

2. Ho KK, Pinsky JL, Kannel WB, Levy D. The epidemiology of heart failure: the Framingham study. J Am Coll Cardiol 1993;22:6-13A

3. Grady KL. Quality of life in patients with chronic heart failure. Crit Care Nurs Clin North Am 1993;661-670.

4. Mayou R, Blackwood R, Bryant B, Garnham J. Cardiac failure: symptoms and functional status. J Psychosom Res 1991;35:399-407.

5. Koenig HG. Depression in hospitalized older patients with congestive heart failure. Gen Hosp Psychiatry 1998;20:29-43.

6. Schall RR, Petrucci RJ, Brozena SC, Cavarocchi NC, Jessup M. Cognitive function in patients with symptomatic dilated cardiomyopathy before and after cardiac transplantation. J Am Coll Cardiol 1989;14:1666-1672. 
7. Cline CMJ, Björck-Linné AK, Israelsson BYA, Willenheimer RB, Erhardt LR. Non-compliance and knowledge of prescribed medication in elderly patients with heart failure. Eur J Heart Failure 1999;1:145-149.

8. Gorkin L, Norvell NK, Rosen RC, et al. Assessment of quality of life as observed from the baseline data of the studies of left ventricular dysfunction (SOLVD) trial quality-of-life substudy. Am J Cardiol 1993;71:1069-1073.

9. Acanfora D, Trojano L, Iannuzzi GL et al. The brain in congestive heart failure. Arch Gerontol Geriatr 1996;247-256.

10. Bornstein RA, Starling RC, Myerowitz P, Haas GJ. Neuropsychological function in patients with end-stage heart failure before and after cardiac transplantation. Acta Neurol Scand 1995;91:260-265.

11. Putzke JD, Williams MA, Rayurn BK, Kirklin JK, Boll TJ. The relationship between cardiac function and neuropsychological status among heart transplant candidates. J Card Fail 1998;4:295-303.

12. Rengo F, Acanfora D, Trojano $L$ et al. Congestive heart failure and cognitive impairment in the elderly. Arch Gerontol Geriatr 1995;20:63-68.

13. Zuccalà G, Cattel C, Manes-Gravina E, Di Niro, MG, Cocchi A, Barnabei $R$. Left ventricular dysfunction: a clue to cognitive impairment in older patients with heart failure. J Neurol Neurosurg Psychiatry 1997;63:509512.
14. Cacciatore F, Abete $\mathrm{P}$, Ferrara $\mathrm{N}$ et al. Congestive heart failure and cognitive impairment in an older population. J Am Geriatr Soc 1998;46:1343-1348.

15. Carlson KJ, Lee DC, Goroll AH, Leahy M, Johnson RA. An analysis of physician's reasons for prescribing long-term digitalis therapy in outpatients. J Chron Dis 1985;38:733-739.

16. New York Heart Association. The Criteria Committee: Diseases of the Heart and Blood Vessels - Nomenclature and Criteria for Diagnosis. New York: Little Brown \& Co, 1979

17. Roth M, Huppert FA, Tym E, Montjoy CQ. CAMDEX: The Cambridge Examination for Mental Disorders of the Elderly. Cambridge: Cambridge University Press, 1988

18. Wechsler D. Wechsler Adult Intelligence Scale-Revised (WAIS-R). San Antonio: The Psychological Corporation, 1981.

19. Lezak M. Neuropsychological Assessment, $3^{\text {rd }}$ edition. Oxford: Oxford University Press, 1995.

20. Statacorp. Stata Statistical Software, Release 6.0. College Station, TX: Stata Corporation, 1999.

21. Putzke JD, Williams MA, Daniel J, Foley BA, Kirklin JK, Boll TJ. Neuropsychological functioning among heart transplant candidates: a case control study. J Clin Exper Neuropsychol 2000;22:95-103. 